\title{
KVALITA ŽıVOTA DĚTÍ A DOSPÍVAJÍCÍCH PO LÉČBĚ ONKOLOGICKÉHO ONEMOCNĚNÍ - POROVNÁNÍ S POHLEDEM JEJICH RODIČŮ
}

\author{
TEREZA BLAŽKOVÁ, MAREK BLATNÝ, TOMÁŠ KEPÁK, \\ MARTIN JELÍNEK, VERONIKA KOUTNÁ
}

\begin{abstract}
Většina studií zabývajících se dětmi a dospívajícími po léčbě onkologického onemocnění poukazuje na dobrou kvalitu života u těchto jedinců. Pohled jejich rodičů se však může výrazně lišit. Mohou se mnohem více obávat o budoucnost a spokojenost svých dětí. Předkládaná studie zjišt’uje rozdíly mezi hodnocením spokojenosti s jednotlivými zdroji kvality života z pohledu samotných dětí a dospívajících a z pohledu jejich rodičů. Současně také sleduje rozdíly mezi jednotlivými věkovými skupinami.

Výzkumný soubor tvoři 172 dětí a dospívajících po léčbě onkologického onemocnění a jejich rodiče. Data, týkající se kvality života dětí a dospívajících po léčbě, byla získána pomocí upraveného Dotazníku kvality života SQUALA.

Hodnocení spokojenosti s jednotlivými zdroji kvality života je velice rozdílné u nejmladší věkové skupiny. Děti uvádějí, že jsou mnohem více spokojené s většinou zdrojů kvality života, a to jak v porovnání se staršími dospívajícími, tak v porovnání s pohledem rodičů.
\end{abstract}

Klíčová slova: děti a dospívající po léčbě onkologického onemocnění, kvalita života, pohled rodičů

https://doi.org/10.14712/23366486.2018.2

\section{Úvod}

Pediatrické onkologické onemocnění je v porovnání s onkologickým onemocněním u dospělých poměrně vzácné, avšak přesto je po úrazech druhou nejčastější prríčinou úmrtí v dětském věku (Národní informační a vzdělávací portál o onkologických onemocněních dětského věku, 2016). Podle dětských onkologických registrů je ročně nově diagnostikováno kolem 360-460 dětí a dospívajících ve věku od 0 do 19 let. Výskyt nových př́ípadů se za posledních 20 let nijak výrazně nezměnil. Jinak je to ovšem s úmrtností, ta se čím dál tím více snižuje ${ }^{1}$ a príbývá tak dětí a dospívajících, kteří onkologické onemocnění přežijí (Národní informační a vzdělávací portál o onkologických onemocněních dětského věku, 2016; Schulte et al., 2016). Onkologické onemocnění v dětském věku a s ním spojená léčba s sebou přináší velmi náročné situace a je zátěží nejen pro děti a dospívající samotné, ale zasahuje do života celé rodiny (Long, Marsland, 2011). I život po ukončení léčby je spojen s mnoha změnami, které se dotýkají opět celé rodiny

\footnotetext{
1 V roce 1993 dle dětského onkologického registru zemřelo 117 dětských pacientů s onkologickým onemocněním. Po roce 2000 však začíná počet registrovaných úmrtí klesat a v roce 2013 se snížil na 53 úmrtí dětských onkologických pacientů.
} 
a jsou velkým zdrojem stresu nejen pro samotného jedince po léčbě, ale také pro rodiče (Woodgate et al., 2016). Kvalita života dětí a dospívajících po léčbě onkologického onemocnění může být ohrožena (Badr et al., 2013). Yi, Kim a Sang (2016) identifikovali oblasti, které dospívajícím po léčbě onkologického onemocnění způsobují největší starosti. Mezi ně patří např́iklad fyzické zdraví, rodina nebo práce a intimní vztahy. Podle výsledků longitudinální studie Lehman et al. (2014), která se zabývala dospívajícími po léčbě onkologického onemocnění, i po 10 letech po ukončení léčby uvádějí dospívající jak negativní, tak pozitivní následky onemocnění a jeho léčby. Tyto pocit’ované následky se však u dospívajících v průběhu přibývajících let od ukončení léčby měnily - některé problémy, ale i pozitivní následky se objevily nově v souvislosti se současným vývojovým obdobím, a naopak některé následky, které dospívající uváděli dříve, se ve starším věku neobjevovaly.

Je proto dủležité, abychom věděli, které oblasti kvality života jsou pro děti a dospívající po léčbě onkologického onemocnění v určitých věkových obdobích nejdůležitější a jak jsou v těchto oblastech spokojeni. Lékaři, zdravotničtí pracovníci i rodiče budou tak moci lépe pomáhat tyto důležité zdroje kvality života rozvíjet a zlepšovat. Neméně důležitý je i pohled rodičů, kteří mají na své děti bezprostřrední vliv, a jejich smýšlení o kvalitě života jejich dítěte se může přenášet na dítě samotné.

\section{Kvalita života u dětí a dospívajících po léčbě onkologického onemocnění}

Přestože jsou léčba onkologického onemocnění i život po ní spojeny s mnoha náročnými situacemi a pozdními následky léčby, mnoho výzkumů poukazuje na srovnatelnou kvalitu života dětí a dospívajících po léčbě onkologického onemocnění v porovnání s vrstevníky z běžné populace a některé výzkumy zjistily dokonce lepší kvalitu života u dětí a dospívajících po léčbě onkologického onemocnění (Blatný et al., 2011; van Dijk et al., 2007; Schulte et al., 2016; Zeltzer et al., 2008). Existují však i studie, které poukazují na zhoršenou kvalitu života u jedinců po léčbě pediatrického onkologického onemocnění (Rueegg et al., 2013).

Tyto rozdílné výsledky mohou být důsledkem např. různého zastoupení diagnóz ve výzkumném vzorku, různou dobou od diagnostikování onkologického onemocnění nebo od ukončení léčby, osobnostními rozdíly či rozdílným věkovým rozložením výzkumného souboru (Bradley-Eilertsen et al., 2012). Některé studie prokazují rozdíly v kvalitě života dětí a dospívajících po léčbě onkologického onemocnění v závislosti na věkovém období. Například v holandské studii (van Dijk et al., 2007) byla u dospívajících po léčbě onkologického onemocnění prokázána nižší kvalita života $\mathrm{v}$ porovnání s mladšími dětmi po léčbě onkologického onemocnění, přestože byla kvalita života obou skupin srovnatelná $\mathrm{s}$ kontrolní skupinou z běžné populace. Shankar et al. (2005) k tomu dodává, že je tady možnost, že mladší děti nedokáží plně zhodnotit negativní dopady onkologického onemocnění na jejich život.

Různé výsledky mezi studiemi týkajícími se hodnocení kvality života dětí a dospívajících po léčbě onkologického onemocnění mohou být také způsobeny rozdílnými nástroji měření kvality života. Např́klad studie Bradley Eilertsen et al. (2012) neprokazuje rozdíly v celkovém hodnocení kvality života dětí a dospívajících po léčbě onkologického onemocnění v porovnání s běžnou populací, ovšem při porovnávání jednotlivých oblastí kvality 
života dosahují v některých př́padech děti a dospívající po léčbě horších výsledků než děti a dospívající z běžné populace. Oblasti kvality života (nebo jejich formulace v dotazníku), které tvoří celkovou kvalitu života, se mohou mezi jednotlivými nástroji měřícími kvalitu života lišit, a to může ovlivnit celkové hodnocení dětí a dospívajících. Schulte et al. (2016) také uvádí, že rozdílné výsledky ohledně kvality života u jedinců po léčbě pediatrického onkologického onemocnění mohou být částečně vysvětleny rozporem mezi hodnocením kvality života samotnými dětmi a dospívajícími po léčbě a z pohledu jejich rodičů.

Bez ohledu na to, jak svou kvalitu života hodnotí děti a dospívající po léčbě onkologického onemocnění, pohled rodičů na kvalitu života jejich dětí se může výrazně lišit (Schulte et al., 2016). Rodiče dětí a dospívajících po onkologickém onemocnění mohou vnímat kvalitu života svých dětí jako horší v porovnání s rodiči dětí stejného věku z běžné populace (van Dijk et al., 2007; Speechley et al., 2006). Některé studie poukazují na rozdílné názory na kvalitu života po léčbě pediatrického onkologického onemocnění ze strany samotných dětí a dospívajících po léčbě a ze strany jejich rodičů, kdy rodiče uvádějí nižší kvalitu života svých dětí po léčbě než děti a dospívající samotní (Gordinj et al., 2013; Schulte et al., 2016; Speechley et al., 2006; Wegenroth et al., 2015). Existuje mnoho vysvětlení těchto rozdílných názorů na kvalitu života dětí a dospívajících po léčbě onkologického onemocnění ze strany rodičů. Eiser a Morse (2001) například uvádějí, že rodiče jsou schopni dobře zhodnotit fyzické aspekty kvality života na rozdíl od aspektů emocionálních a sociálních. Rozdíly mohou být také způsobeny obavami rodičů o budoucnost svého dítěte. Eiser, Eiser a Greco (2004) ve své studii zjistili, že rodiče, kteří byli pesimističtí ohledně budoucnosti svého dítěte, ohodnotili také jeho kvalitu života jako horší. Jiné studie naznačují, že se děti a dospívající po léčbě onkologického onemocnění více snaží označovat sociálně žádoucí odpovědi, a proto hodnotí svou kvalitu života lépe, než jak je tomu ve skutečnosti (Gordinj, 2013). Jiným důvodem, proč děti a dospívající po léčbě hodnotí svou kvalitu života jinak, než ji vnímají jejich rodiče, může být získání lepších schopností vyrovnat se s nepríznivými událostmi v životě díky zvládnutí onkologického onemocnění nebo větší vděčnost a ocenění toho, být naživu, v důsledku prodělání onkologického onemocnění a léčby s ním spojené (van Dijk et al., 2007). Podle Bradley Eilertsen et al. (2012) je tento rozdíl v hodnocení kvality života především důsledkem různých pohledů na zdraví dětí a dospívajících, ovšem autoři také zdůrazňují, že nelze hodnotit, který z pohledů na kvalitu života je správný.

\section{Cíle studie}

Předkládaná studie je součástí brněnského prospektivního longitudinálního projektu QOLOP (Quality of Life Longitudinal Study in Pediatric Oncology Patients), který běží již od roku 2006 a zabývá se subjektivním sledováním kvality života u dětí a dospívajících po léčbě onkologického onemocnění. $\mathrm{V}$ předchozích studiích $\mathrm{v}$ rámci projektu QOLOP byla zjištěna srovnatelná a v některých oblastech dokonce lepší úroveň kvality života u dětí a dospívajících po léčbě onkologického onemocnění (Blatný et al., 2011), a to i při opakovaném měření kvality života s odstupem několika let (Blatný, Jelínek, Kepák, 2016).

V předkládané studii si klademe za cíl zjistit, jaké zdroje kvality života jsou pro děti a dospívající po léčbě onkologického onemocnění nejdůležitější v různých věkových obdobích, jak jsou s těmito zdroji kvality života spokojeni a zda existují rozdíly 
v hodnocení zdrojů kvality života mezi věkovými skupinami. Dalším cílem je zjistit, zda se liší pohled rodičů na spokojenost svých dětí s jednotlivými zdroji kvality života s pohledem samotných dětí a dospívajících po léčbě onkologického onemocnění, tedy porovnat hodnocení spokojenosti se zdroji kvality života dětí a dospívajících po léčbě onkologického onemocnění z pohledu rodičů s vlastním hodnocením dětí a dospívajících po léčbě. Vzhledem $\mathrm{k}$ tomu, že sběr dat stále probíhá a data $\mathrm{z}$ druhé vlny longitudinálního projektu QOLOP nejsou prozatím kompletní, byla z důvodů potřeby velkého souboru dat použita data pouze z první vlny.

Na základě výsledků studií, které se mimo jiné zabývaly rozdílem v hodnocení kvality života v různých věkových obdobích (např. van Dijk et al., 2007), předpokládáme větší udávanou spokojenost s kvalitou života u mladších dětí v porovnání se staršími dospívajícími. Co se týče rodičovského hodnocení kvality života, v souladu s jinými studiemi předpokládáme, že rodiče vnímají spokojenost se zdroji kvality života jako horší, než ji hodnotí samotné děti a dospívající po léčbě onkologického onemocnění.

\section{Studie}

\section{Výzkumný soubor}

Výzkumný soubor tvořili děti a dospívající po léčbě onkologického onemocnění a jejich rodiče, kteří jsou zapojeni do projektu QOLOP, který se zabývá kvalitou života a ostatními psychosociálními souvislostmi života dětí a dospívajících po léčbě onkologického onemocnění. Do předkládané studie bylo zapojeno 172 dětí a dospívajících (79 dívek a 93 chlapců) ve věku od 10 let do 18 let a jejich rodiče. Co se týče diagnóz ve výzkumném vzorku, leukémii mělo diagnostikováno celkem $20 \%$ dětí a dospívajících a nádor CNS mělo diagnostikováno $25 \%$ dětí a dospívajících. Zbývajících $55 \%$ bylo zastoupeno jinými typy pediatrického onkologického onemocnění. Všechny děti a dospívající byli v době sběru dat v rozmezí od 8 do 140 měsíců v remisi onkologického onemocnění. Až 38 \% dětí a dospívajících po léčbě netrpělo žádnými pozdními následky léčby. Pouze nízké pozdní následky pocit’ovalo 33 \% dětí a dospívajících a nejzávažnější pozdní následky udávalo $24 \%$ dětí a dospívajících (viz Tabulka 1). Pro účely studie byli děti a dospívající rozděleni do tří věkových skupin - děti ve věku od 10 let do 12 let, mladší dospívající ve věku od 13 let do 14 let a starší dospívající ve věku od 15 let do 18 let. Podrobnější popis souboru dle skupin uvádí Tabulka 1.

\section{Použité metody}

Data týkající se kvality života dětí a dospívajících po léčbě onkologického onemocnění byla získána pomocí Dotazníku kvality života SQUALA (Dragomirecká et al., 2006), který byl pro účely projektu QOLOP upraven pro použití u dětí a dospívajících po léčbě onkologického onemocnění (viz Př́lohy). Upravená verze Dotazníku kvality života SQUALA obsahuje 30 zdrojů kvality života (např. fyzická soběstačnost, zdraví, dobrý spánek, rodinné vztahy, intimní vztahy, možnost chodit do školy, trávení volného času apod.) a byl účastníkům předkládán ve dvou formách - první forma je určena pro děti a dospívající, ve které účastníci hodnotí nejdříve, jak moc jsou pro ně určité zdroje kvality života důležité na pětibodové stupnici od 1 (vůbec není důležité) do 5 (naprosto nezbytné). Následně hodnotí spokojenost s těmito zdroji kvality života opět na pětibodové stupnici od 1 (naprosto 
nespokojený/á) až po 5 (naprosto spokojený/á). Druhá verze upraveného Dotazníku kvality života SQUALA, která je určena pro rodiče, obsahuje pouze položky zjišt’ující domnívanou spokojenost dětí a dospívajících po léčbě s určitými zdroji kvality života opět na pětibodové stupnici od 1 (naprosto nespokojený/á) do 5 (naprosto spokojený/á).

Sběr dat probíhal na Klinice dětské onkologie FN Brno. Účastníky k zapojení do projektu QOLOP oslovovala zdravotní sestra v rámci pravidelných prohlídek dětí a dospívajících po léčbě onkologického onemocnění. Dětem a dospívajícím i jejich rodičům byl vysvětlen účel i veškeré podrobnosti vyšetření a následně byl rodičům předložen k podpisu informovaný souhlas s účastí ve studii schválený etickou komisí FN Brno. Podmínkou účasti ve studii bylo diagnostikování onkologického onemocnění v dětském věku a absolvování léčby onkologického onemocnění chemoterapií nebo radioterapií.

Ke statistickému zpracování dat byla použita deskriptivní statistika, faktoriální ANOVA a neparametrický Wilcoxonův signed rank test s použitím programu SPSS.

\section{Výsledky}

V Tabulce 2 můžeme vidět hodnocení důležitosti jednotlivých zdrojů kvality života různými věkovými skupinami. U dětí ve věku od 10 do 12 let byly jako nejdůležitější hodnoceny rodinné vztahy a zdraví. U mladších dospívajících (13-14 let) byla považována

Tabulka 1 Popis souboru děti a dospívajicich po léčbě onkologického onemocnění

\begin{tabular}{|c|c|c|c|c|}
\hline & $\begin{array}{c}\text { Celkem } \\
(\mathrm{N}=172)\end{array}$ & $\begin{array}{c}\text { Věková skupina } \\
10-12 \text { let } \\
(\mathrm{N}=60)\end{array}$ & $\begin{array}{c}\text { Věková skupina } \\
13-14 \text { let } \\
(\mathrm{N}=43)\end{array}$ & $\begin{array}{c}\text { Věková skupina } \\
15-18 \text { let } \\
(\mathrm{N}=69)\end{array}$ \\
\hline Věk (m (sd)) & $13,8(2,6)$ & $10,8(0,8)$ & $13,7(0,7)$ & $16,5(1,0)$ \\
\hline \multicolumn{5}{|l|}{ Pohlaví (n (\%)) } \\
\hline Dívky & $79(46 \%)$ & $33(55 \%)$ & $14(33 \%)$ & $32(46 \%)$ \\
\hline Chlapci & $93(54 \%)$ & $27(45 \%)$ & $29(67 \%)$ & $37(54 \%)$ \\
\hline \multicolumn{5}{|l|}{ Diagnóza (n (\%)) } \\
\hline Leukémie & $35(20 \%)$ & $20(33 \%)$ & $8(19 \%)$ & $7(10 \%)$ \\
\hline Nádory CNS & $42(25 \%)$ & $18(30 \%)$ & $10(23 \%)$ & $14(20 \%)$ \\
\hline Jiné nádory & $95(55 \%)$ & $22(37 \%)$ & $25(58 \%)$ & $48(70 \%)$ \\
\hline \multicolumn{5}{|c|}{ Doba od ukončení léčby (n (\%)) } \\
\hline do 36 měsíců & $82(48 \%)$ & $34(57 \%)$ & $18(42 \%)$ & $30(43 \%)$ \\
\hline 36-60 měsíců & $46(27 \%)$ & $14(23 \%)$ & $10(23 \%)$ & $22(32 \%)$ \\
\hline nad 60 měsíců & $44(25 \%)$ & $12(20 \%)$ & $15(35 \%)$ & $17(25 \%)$ \\
\hline \multicolumn{5}{|c|}{ Závažnost pozdních následků (n (\%)) } \\
\hline Žádné pozdní následky & $65(38 \%)$ & $24(40 \%)$ & $16(37 \%)$ & $25(36 \%)$ \\
\hline Nízká & $57(33 \%)$ & $20(33 \%)$ & $10(23 \%)$ & $27(39 \%)$ \\
\hline Střední & $26(15 \%)$ & $8(13 \%)$ & $6(14 \%)$ & $12(18 \%)$ \\
\hline Vysoká & $24(24 \%)$ & $8(13 \%)$ & $11(26 \%)$ & $5(7 \%)$ \\
\hline
\end{tabular}


za nejdůležitější buducí práce, dále potom zdraví a rodinné vztahy. Pro starší dospívající (15-18 let) je nejdůležitější nebýt odkázán na pomoc druhých, zdraví, budoucí práce a kamarádi.

Tabulka 2 zobrazuje spokojenost s jednotlivými zdroji kvality života tak, jak ji hodnotili samotné děti a dospívající. Děti (10-12 let) jsou nejvíce spokojeny se svým zdravím a s věcmi, které mají pro zábavu. Dále jsou velmi spokojeny s rodinnými vztahy. Mladší dospívající mezi 13-14 lety jsou velmi spokojeni také s př́ijemným prostředím, ve kterém žijí. Dále jsou spokojeni se vztahy se svými kamarády. Starší dospívající (15-18 let) jsou nejvíce spokojeni s tím, že nejsou odkázáni na pomoc druhých, což mimochodem hodnotili jako nejdůležitější zdroj kvality života.

Co se týče rozdílů v hodnocení důležitosti jednotlivých zdrojů kvality života mezi jednotlivými věkovými skupinami (viz Tabulku 2) byl prokázán signifikantní rozdíl mezi dětmi (10-12 let) a mladšími dospívajícími (13-14 let) v hodnocení intimních vztahů, hezkého oblečení a hezkých věcí. Dále byly prokázány signifikantní rozdíly mezi dětmi (10-12 let) a staršími dospívajícími (15-18 let) v hodnocení důležitosti fyzické soběstačnosti, intimních vztahů a víry. Mezi mladšími dospívajícími (13-14 let) a staršími dospívajícími (15-18 let) byly nalezeny signifikantní rozdíly ve zdrojích fyzické soběstačnosti, zábava a hezké věci.

Při hodnocení spokojenosti s jednotlivými zdroji kvality života (viz Tabulku 3) byly prokázány signifikantní rozdíly mezi dětmi (10-12 let) a mladšími dospívajícími (13-14 let) ve zdrojích zdraví, spravedlnost, pravda a hezké věci. Dále byly nalezeny signifikantní rozdíly mezi dětmi (10-12 let) a staršími dospívajícími (15-18 let) ve zdrojích zdraví, fyzická soběstačnost, spánek, rodina, péče o sebe, intimní vztahy, odpočinek, záliby, spravedlnost, pravda, peníze, dobré jídlo, vzdělání, zábava, vzhled, hezké oblečení a hezké věci. Mezi mladšími dospívajícími (13-14 let) a staršími dospívajícími (15-18 let) byly prokázány rozdíly v hodnocení spokojenosti se zdroji odpočinek, spravedlnost, peníze, dobré jídlo a zábava. Přestože tyto výsledky poukazují na rozdíly v hodnocení spokojenosti mezi věkovými skupinami, v průměru jsou všichni s jednotlivými oblastmi kvality života spokojeni ${ }^{2}$.

Rozdíly v hodnocení spokojenosti dětí a dospívajících po léčbě onkologického onemocnění z pohledu rodičů a dětí a dospívajících samotných zobrazuje Tabulka 4 . Signifikantní rozdíly byly nalezeny především u dětí (10-12 let), a to ve zdrojích zdraví, psychická pohoda, rodina, kamarádi, mezilidské vztahy, intimní vztahy, záliby, spravedlnost, pravda, peníze, vzdělání, škola, trávení volného času, zábava, vzhled a hezké věci. Rodiče u všech uvedených zdrojů hodnotili spokojenost hůře než děti samotné. U mladších dospívajících (13-14 let) byly nalezeny signifikantní rozdíly mezi pohledem rodičů a dětí a dospívajících ve zdrojích prostředí a domov, kamarádi, spravedlnost, peníze, hezké oblečení a hezké věci. Stejně jako u dětí i v případě mladších dospívajících rodiče vnímali spokojenost svých dětí se zdroji kvality života hưre než samotné děti a dospívající. U starších dospívajících (15-18 let) byly nalezeny signifikantní rozdíly mezi pohledem rodičů a dospívajících u zdrojů spánek, péče o sebe, intimní vztahy, zájem o svět kolem, odpočinek a bezpečí. V př́ípadě starších dospívajících (15-18 let) hodnotili rodiče spokojenost svých dětí lépe, než ji vnímají sami dospívající.

2 Rozsah škály hodnotící spokojenost s jednotlivými oblastmi života je 1 (naprosto nespokojený/á) až 5 (naprosto spokojený/á), teoretický průmět je tedy 2,5 . Nejnižší hodnocení dětmi a dospívajícími po léčbě se pohybuje kolem 2,8 u starších dospívajících při hodnocení spokojenosti se spravedlností. 
Tabulka 2 Průměry hodnoceni důležitosti oblasti kvality života a rozdily v hodnoceni dưležitosti oblastí kvality života mezi věkovými skupinami

\begin{tabular}{|c|c|c|c|c|c|c|c|c|}
\hline & \multicolumn{6}{|c|}{ Věková skupina } & \multirow{3}{*}{$\mathrm{F}$} & \multirow{3}{*}{ Sig. } \\
\hline & \multicolumn{2}{|c|}{$10-12$ let } & \multicolumn{2}{|c|}{ 13-14 let } & \multicolumn{2}{|c|}{ 15-18 let } & & \\
\hline & M & SD & M & SD & M & SD & & \\
\hline Zdraví & 4,32 & 0,676 & 4,42 & 0,587 & 4,40 & 0,813 & 0,31 & 0,732 \\
\hline Fyzická soběstačnost & 3,56 & 1,038 & 3,91 & 1,151 & 4,49 & 0,877 & 13,77 & $0,000^{* *}, * * *$ \\
\hline Psychická pohoda & 4,27 & 0,710 & 4,30 & 0,638 & 4,12 & 0,702 & 1,19 & 0,307 \\
\hline Prostředí a domov & 3,81 & 0,900 & 4,00 & 0,756 & 3,79 & 0,873 & 0,87 & 0,425 \\
\hline Spánek & 3,92 & 0,907 & 4,02 & 0,963 & 3,81 & 0,902 & 0,73 & 0,483 \\
\hline Rodina & 4,42 & 0,619 & 4,33 & 0,644 & 4,19 & 0,802 & 1,61 & 0,203 \\
\hline Kamarádi & 4,20 & 0,732 & 4,33 & 0,680 & 4,26 & 0,803 & 0,36 & 0,700 \\
\hline Mezilidské vztahy & 3,82 & 0,770 & 3,95 & 0,872 & 3,81 & 0,902 & 0,54 & 0,582 \\
\hline Péče o sebe & 3,75 & 0,914 & 3,95 & 0,785 & 3,93 & 0,698 & 1,08 & 0,343 \\
\hline Intimní vztahy & 2,55 & 1,320 & 3,33 & 1,040 & 3,34 & 0,978 & 9,49 & $0,000^{*}, * *$ \\
\hline Zájem o svět kolem & 3,15 & 0,936 & 3,17 & 1,034 & 3,12 & 0,890 & 0,04 & 0,962 \\
\hline Víra & 2,77 & 1,477 & 2,23 & 1,172 & 2,09 & 1,255 & 4,50 & $0,012^{* *}$ \\
\hline Odpočinek & 3,33 & 0,986 & 3,12 & 1,074 & 3,15 & 0,935 & 0,80 & 0,453 \\
\hline Záliby & 3,73 & 1,087 & 4,00 & 0,816 & 3,51 & 1,113 & 2,90 & 0,058 \\
\hline Bezpečí & 4,20 & 0,805 & 4,07 & 0,669 & 3,85 & 0,950 & 2,84 & 0,061 \\
\hline Spravedlnost & 4,25 & 0,632 & 4,14 & 0,710 & 3,99 & 0,782 & 2,26 & 0,107 \\
\hline Pravda & 4,10 & 0,817 & 4,09 & 0,610 & 4,16 & 0,725 & 0,16 & 0,852 \\
\hline Peníze & 2,98 & 1,017 & 3,35 & 0,897 & 3,32 & 1,029 & 2,43 & 0,091 \\
\hline Dobré jídlo & 3,49 & 0,917 & 3,49 & 0,935 & 3,47 & 0,969 & 0,01 & 0,991 \\
\hline Vzdělání & 4,02 & 1,025 & 4,12 & 0,762 & 4,09 & 0,707 & 0,20 & 0,821 \\
\hline Škola & 4,00 & 0,991 & 3,79 & 0,951 & 3,81 & 0,885 & 0,89 & 0,414 \\
\hline Trávení volného času & 3,70 & 0,908 & 3,98 & 0,886 & 4,03 & 0,946 & 2,25 & 0,108 \\
\hline Zábava & 3,23 & 0,981 & 3,77 & 0,947 & 3,49 & 1,000 & 3,74 & $0,026^{* * *}$ \\
\hline Vzhled & 3,35 & 1,055 & 3,60 & 0,821 & 3,28 & 0,861 & 1,70 & 0,186 \\
\hline Hezké oblečení & 3,23 & 1,047 & 3,74 & 0,848 & 3,32 & 0,937 & 3,91 & $0,022^{*}$ \\
\hline Hezké věci & 3,02 & 1,066 & 3,51 & 0,925 & 3,01 & 1,000 & 3,78 & $0,025^{*}, * * *$ \\
\hline
\end{tabular}

* Signifikantní rozdíl mezi dětmi (10-12 let) a mladšími dospívajícími (13-14 let)

** Signifikantní rozdíl mezi dětmi (10-12 let) a staršími dospívajícími (15-18 let)

*** Signifikantní rozdíl mezi mladšími dospívajícími (13-14 let) a staršími dospívajícími (15-18let) 
Tabulka 3 Prüměry hodnoceni spokojenosti s oblastmi kvality života a rozdily v hodnoceni spokojenosti s oblastmi kvality života mezi věkovými skupinami

\begin{tabular}{|c|c|c|c|c|c|c|c|c|}
\hline & \multicolumn{6}{|c|}{ Věková skupina } & \multirow{3}{*}{$\mathrm{F}$} & \multirow{3}{*}{ Sig. } \\
\hline & \multicolumn{2}{|c|}{$10-12$ let } & \multicolumn{2}{|c|}{ 13-14 let } & \multicolumn{2}{|c|}{ 15-18 let } & & \\
\hline & M & SD & M & SD & M & $\mathrm{SD}$ & & \\
\hline Zdraví & 4,67 & 0,63 & 4,14 & 1,04 & 3,96 & 0,98 & 10,60 & $0,000^{*}, * *$ \\
\hline Fyzická soběstačnost & 4,34 & 0,76 & 4,49 & 0,67 & 4,65 & 0,62 & 3,24 & $0,042^{* *}$ \\
\hline Psychická pohoda & 4,27 & 0,887 & 4,26 & 0,819 & 4,07 & 0,841 & 1.01 & 0,366 \\
\hline Prostředí a domov & 4,65 & 0,606 & 4,63 & 0,587 & 4,38 & 0,713 & 3,31 & 0,061 \\
\hline Spánek & 4,49 & 0,92 & 4,40 & 0,90 & 4,09 & 1,02 & 3,10 & $0,049^{* *}$ \\
\hline Rodina & 4,65 & 0,63 & 4,35 & 0,81 & 4,10 & 0,95 & 7,18 & $0,001^{* *}$ \\
\hline Kamarádi & 4,40 & 0,848 & 4,53 & 0,813 & 4,26 & 0,803 & 1,55 & 0,216 \\
\hline Mezilidské vztahy & 4,22 & 0,930 & 4,14 & 0,710 & 3,94 & 0,814 & 1,88 & 0,156 \\
\hline Péče o sebe & 4,23 & 0,87 & 4,19 & 0,83 & 3,87 & 0,79 & 3,62 & $0,029^{* *}$ \\
\hline Intimní vztahy & 3,88 & 1,04 & 3,67 & 1,03 & 3,41 & 1,11 & 3,10 & $0,048^{* *}$ \\
\hline Zájem o svět kolem & 4,19 & 0,840 & 4,14 & 0,833 & 3,93 & 0,834 & 1,72 & 0,182 \\
\hline Víra & 4,27 & 0,954 & 4,05 & 1,024 & 4,09 & 0,942 & 0,80 & 0,453 \\
\hline Odpočinek & 4,46 & 0,82 & 4,44 & 0,83 & 4,04 & 0,82 & 5,04 & $0,008^{* *}, * * *$ \\
\hline Záliby & 4,62 & 0,69 & 4,42 & 0,79 & 4,04 & 0,99 & 7,47 & $0,001^{* *}$ \\
\hline Bezpečí & 4,50 & 0,701 & 4.37 & 0,846 & 4,26 & 0,704 & 1,61 & 0,204 \\
\hline SpravedInost & 4,02 & 1,12 & 3,44 & 1,03 & 2,84 & 1,07 & 18,88 & $0,000^{*}, * *, * * *$ \\
\hline Pravda & 3,90 & 1,12 & 3,28 & 0,91 & 2,91 & 1,00 & 15,07 & $0,000^{*}, * *$ \\
\hline Peníze & 4,19 & 0,96 & 3,95 & 0,87 & 3,38 & 0,88 & 13,14 & $0,000^{* *}, * * *$ \\
\hline Dobré jídlo & 4,50 & 0,72 & 4,51 & 0,63 & 4,13 & 0,83 & 5,11 & $0,007^{* *}, * * *$ \\
\hline Vzdělání & 4,47 & 0,83 & 4,12 & 0,88 & 4,03 & 0,73 & 5,03 & $0,008^{* *}$ \\
\hline Škola & 4,40 & 0,924 & 4,05 & 1,022 & 4,21 & 0,839 & 1,91 & 0,151 \\
\hline Trávení volného času & 4,62 & 0,761 & 4,33 & 0,892 & 4,26 & 0,874 & 3,04 & 0,051 \\
\hline Zábava & 4,67 & 0,51 & 4,47 & 0,59 & 4,01 & 0,86 & 14,90 & $0,000^{* *}, * * *$ \\
\hline Vzhled & 4,15 & 0,99 & 3,95 & 1,02 & 3,57 & 0,94 & 5,76 & $0,004^{* *}$ \\
\hline Hezké oblečení & 4,47 & 0,77 & 4,40 & 0,66 & 4,15 & 0,61 & 3,86 & $0,023^{* *}$ \\
\hline Hezké věci & 4,60 & 0,62 & 4,21 & 0,71 & 3,90 & 0,87 & 14,00 & $0,000^{*}, * *$ \\
\hline
\end{tabular}

* Signifikantní rozdíl mezi dětmi (10-12 let) a mladšími dospívajícími (13-14 let)

** Signifikantní rozdíl mezi dětmi (10-12 let) a staršími dospívajícími (15-18 let)

*** Signifikantní rozdíl mezi mladšími dospívajícími (13-14 let) a staršími dospívajícími (15-18let) 
Tabulka 4 Rozdíly v hodnocení spokojenosti dètí a dospivajicich po léčbě s jednotlivými zdroji kvality života z pohledu roiču a samotných dètí a dospivajicich

\begin{tabular}{|c|c|c|c|c|c|c|}
\hline & \multicolumn{6}{|c|}{ Věková skupina } \\
\hline & \multicolumn{2}{|c|}{ 10-12 let } & \multicolumn{2}{|c|}{ 13-14 let } & \multicolumn{2}{|c|}{ 15-18 let } \\
\hline & $\mathrm{Z}$ & Sig. & Z & Sig. & $\mathrm{Z}$ & Sig. \\
\hline Zdraví & $-4,58$ & 0,000 & $-1,36$ & 0,173 & $-0,35$ & 0,730 \\
\hline Fyzická soběstačnost & $-0,66$ & 0,509 & $-0,95$ & 0,342 & $-1,49$ & 0,135 \\
\hline Psychická pohoda & $-2,27$ & 0,023 & $-1,32$ & 0,186 & $-0,77$ & 0,439 \\
\hline Prostředí a domov & $-1,62$ & 0,105 & $-2,54$ & 0,011 & $-0,89$ & 0,376 \\
\hline Spánek & $-0,41$ & 0,686 & $-1,04$ & 0,299 & $-3,12$ & 0,002 \\
\hline Rodina & $-3,56$ & 0,000 & $-1,89$ & 0,059 & 0,00 & 1,000 \\
\hline Kamarádi & $-4,48$ & 0,000 & $-3,06$ & 0,002 & $-0,38$ & 0,704 \\
\hline Mezilidské vztahy & $-3,31$ & 0,001 & $-1,68$ & 0,093 & $-0,53$ & 0,598 \\
\hline Péče o sebe & $-1,68$ & 0,094 & $-0,92$ & 0,358 & $-3,13$ & 0,002 \\
\hline Intimní vztahy & $-1,99$ & 0,047 & $-0,16$ & 0,875 & $-2,19$ & 0,028 \\
\hline Zájem o svět kolem & $-1,79$ & 0,073 & $-0,47$ & 0,639 & $-3,06$ & 0,002 \\
\hline Víra & $-1,40$ & 0,162 & $-0,16$ & 0,875 & $-1,27$ & 0,203 \\
\hline Odpočinek & $-1,48$ & 0,138 & $-1,08$ & 0,280 & $-3,46$ & 0,001 \\
\hline Záliby & $-3,21$ & 0,001 & $-1,95$ & 0,051 & $-0,99$ & 0,323 \\
\hline Bezpečí & $-0,54$ & 0,591 & $-1,37$ & 0,170 & $-2,07$ & 0,038 \\
\hline Spravedlnost & $-3,52$ & 0,000 & $-3,09$ & 0,002 & $-1,15$ & 0,252 \\
\hline Pravda & $-3,71$ & 0,000 & $-0,90$ & 0,370 & $-1,07$ & 0,285 \\
\hline Peníze & $-2,88$ & 0,004 & $-2,51$ & 0,012 & $-0,43$ & 0,666 \\
\hline Dobré jídlo & $-1,95$ & 0,051 & $-1,84$ & 0,066 & $-0,63$ & 0,526 \\
\hline Vzdělání & $-2,23$ & 0,026 & $-1,91$ & 0,057 & $-1,02$ & 0,306 \\
\hline Škola & $-3,62$ & 0,000 & $-1,25$ & 0,210 & $-0,14$ & 0,889 \\
\hline Trávení volného času & $-3,35$ & 0,001 & $-1,72$ & 0,086 & $-0,52$ & 0,602 \\
\hline Zábava & $-2,36$ & 0,018 & $-1,79$ & 0,074 & $-1,71$ & 0,088 \\
\hline Vzhled & $-3,27$ & 0,001 & $-0,95$ & 0,344 & $-1,84$ & 0,066 \\
\hline Hezké oblečení & $-1,88$ & 0,060 & $-2,10$ & 0,036 & $-0,25$ & 0,803 \\
\hline Hezké věci & $-3,87$ & 0,000 & $-1,99$ & 0,047 & $-0,10$ & 0,921 \\
\hline
\end{tabular}




\section{Diskuze}

Předkládaná studie popisuje nejdůležitější zdroje kvality života a spokojenost s nimi u jedinců po léčbě pediatrického onkologického onemocnění v různých věkových obdobích. Studie se zaměřuje také na hodnocení spokojenosti s jednotlivými zdroji kvality života u dětí a dospívajících po léčbě onkologického onemocnění z pohledu jejich rodičů a zjištění rozdílů mezi hodnocením rodičů s vlastním hodnocením dětí a dospívajících po léčbě.

Jedním z nejdůležitějších zdrojů kvality života je zdraví, a to pro všechny děti a dospívající po léčbě onkologického onemocnění bez ohledu na věkové období. U dětí a dospívajících po léčbě onkologického onemocnění je jejich budoucí zdraví jednou z největších starostí. Důležitost zdraví u těchto jedinců dokazuje např. i studie Yi, Kim a Sang (2016), ve které bylo zjištěno, že se jedinci po léčbě dětského onkologického onemocnění častěji vyhýbají rizikovému chování, aby co nejvíce své zdraví ochránili a udělali maximum, aby minimalizovali riziko návratu onemocnění (Yi, Kim, Sang, 2016). Je tedy vcelku logické, že zdraví je stabilně velmi důležitou součástí kvality života bez ohledu na věkové období, ve kterém se zrovna jedinci po léčbě onkologického onemocnění nacházejí.

V hodnocení důležitosti dalších zdrojů kvality života se však již objevují rozdíly v závislosti na věkovém období. Zatímco pro děti ve věku od 10 do 12 let je nejdůležitější mít dobré rodinné vztahy, mladší dospívající ve věku od 13 do 14 let již pomalu začínají přemýšlet o své budoucnosti a stává se pro ně nejdůležitější mít jednou zaměstnání, které je bude bavit. U dospívajících můžeme pozorovat větší orientaci do budoucnosti, oproti dětem, které více žijí přítomností a tím, co je „tady a nyni““ (Bradley Eilertsen et al., 2012). U starších dospívajících ve věku od 15 do 18 let se do popředí nejvíce dostává potřeba být soběstačný a samostatný v běžných denních činnostech (fyzická soběstačnost). U obou skupin dospívajících můžeme sledovat postupný nárůst důležitosti kamarádů, při současném poklesu v hodnocení důležitosti rodiny jako zdroje kvality života. Postupné uvolňování se od vlivu rodiny a přibývání důležitosti kamarádů a vrstevníků se vzrůstajícím věkem u dětí a dospívajících po léčbě onkologického onemocnění již bylo prokázáno mnoha studiemi (Decker, 2007; Koutná et al., 2014; Ritchie, 2001). Přestože se důležitost rodiny jako zdroje kvality života s postupem věku snižuje, stále zůstává pro dospívající po léčbě velmi důležitá.

Nejvíce rozdílné hodnocení důležitosti jednotlivých zdrojů kvality života existuje mezi dětmi (10-12 let) a staršími dospívajícími (15-18 let). Největší rozdíl můžeme pozorovat $\mathrm{v}$ hodnocení důležitosti nebýt odkázán na pomoc druhých při běžné denní činnosti (fyzická soběstačnost). Tento zdroj kvality života byl signifikantně nejdůležitější pro starší dospívající ve věku od 15 do 18 let v porovnání s oběma dalšími věkovými skupinami. Dalším velmi rozdílným zdrojem kvality života vzhledem k věkovému období jsou intimní vztahy a potřeba s někým chodit. Tento zdroj kvality života je u dětí (10-12 let) nejméně důležitým zdrojem kvality života a signifikantně se liší od obou starších věkových skupin.

Co se týče spokojenosti s důležitými zdroji kvality života, zatímco děti ve věku od 10 do 12 let byly velmi spokojené se svým zdravím (dokonce u nich je spokojenost se zdravím na prvním místě), u obou starších věkových skupin (13 až 14 let i 15 až 18 let) se spokojenost se svým současným zdravím objevuje až na 17. místě. Výsledky částečně korespondují se závěry studií (Speechley et al., 2006; Wegenroth et al., 2015), které 
dokazují, že fyzické zdraví je jednou z nejhůře hodnocených oblastí kvality života u dětí a dospívajících po léčbě onkologického onemocnění. Tyto studie však nerozlišují mezi jednotlivými věkovými obdobími. Mladší dospívající ve věku od 13 do 14 let byli nevíce spokojeni s prostředím, ve kterém žijí, které ale není mezi těmi nejdůležitějšími zdroji kvality života ${ }^{3}$. Dospívající ve věku od 15 do 18 let byli nejspokojenější s tím, jak jsou fyzicky soběstační, tzn. nezávislí na pomoci druhých při běžné denní činnosti, což hodnotili i jako nejdůležitější zdroj kvality života. Zajímavé je, že hodnocení spokojenosti s rodinnými vztahy, jakožto velmi důležitého zdroje kvality života bez ohledu na věkové období, se s přibývajícím věkem snižuje. Mezi dětmi a staršími dospívajícími je rozdíl se spokojeností rodinných vztahů dokonce signifikantní. Jedním z možných vysvětlení je přehnaná péče a strach ze strany rodičů, což již v tomto věkovém období může být dospívajícím na obtíž (Yi, Kim, Sang, 2016).

Nejvíce spokojené se zdroji kvality života jsou děti ve věku od 10 do 12 let, ovšem se dvěma výjimkami, a to s hodnocením spokojenosti s tím, jak jsou nezávislé na pomoci druhých lidí při běžné denní činnosti (fyzická soběstačnost) a se svými kamarády. S fyzickou soběstačností jsou nejvíce spokojeni starší dospívající ve věku od 15 do 18 let, dokonce signifikantně více než děti (10-12 let). Se svými kamarády jsou více spokojeni mladší dospívající (13-14 let), avšak tento rozdíl není signifikantní. Největší rozdíly v hodnocení spokojenosti s různými zdroji kvality života jsou mezi dětmi (10-12 let) a staršími dospívajícími (15-18 let), a to vždy (s výjimkou již výše zmiňované fyzické soběstačnosti) s menší spokojeností se zdroji kvality života ze strany starších dospívajících (15-18 let). Mezi bližšími věkovými skupinami, tj. mezi dětmi a mladšími dospívajícími, stejně jako mezi mladšími dospívajícími a staršími dospívajícími se objevuje méně signifikantních rozdílů než mezi dětmi a staršími dospívajícími.

Výše uvedené výsledky poukazují, podobně jako u hodnocení důležitosti, na postupnou změnu hodnocení spokojenosti v závislosti na věkovém období. Zatímco mezi bližšími věkovými skupinami existuje pouze pár signifikantních rozdílů v hodnocení spokojenosti s jednotlivými zdroji kvality života, mezi dětmi a staršími dospívajícími jsou již tyto rozdíly u více než poloviny zdrojů kvality života.

Druhým cílem předkládané studie bylo porovnat hodnocení spokojenosti s různými zdroji kvality života dětí a dospívajících z pohledu samotných dětí a dospívajících s pohledem jejich rodičů.

Nejvíce rozdílů v hodnocení spokojenosti s různými zdroji kvality života existuje mezi pohledem rodičů a dětmi ve věku od 10 do 12 let. Rodiče hodnotí spokojenost až s 16 zdroji kvality života hůře, než ji vnímají děti samotné. Tyto rozdíly mohou být způsobeny napríílad omezením kognitivních schopností u dětí vzhledem k vývojovému období (Eiser, Morse, 2001), v důsledku čehož děti nedokáží plnohodnotně posoudit a reflektovat vliv nemoci na jejich život a jsou ještě moc malé na to, aby se již setkaly s některými negativními psychosociálními dopady onkologického onemocnění a jeho léčby (Shankar et al., 2005). Yi, Kim a Sang (2016) uvádějí, že se s přibývajícím věkem mohou objevit nové problémy způsobené onkologickým onemocněním a jeho léčbou, které jedinci po léčbě v mladších věkových obdobích nezažívali a které mohou ovlivnit vnímání kvality jejich života až v pozdějších věkových obdobích. Rozdíly mezi pohledem rodičů a dětí

Mezi mladšími dospívajícími bylo nejdůležitějším zdrojem kvality života mít v budoucnu dobré zaměstnání, to se však logicky při posuzování spokojenosti nehodnotí. 
mohou být také způsobeny pesimistickým pohledem na budoucnost svých dětí ze strany rodičů (Eiser, Eiser \& Greco, 2004).

U obou starších věkových skupin je rozdíl mezi pohledem rodičů a vlastním hodnocením dospívajících menší. Za zmínku stojí fakt, že spokojenost s některými zdroji kvality života hodnotili starší dospívající signifikantně hůře, než ji vnímali jejich rodiče. Tyto rozdíly jsou především v hodnocení spokojenosti se spánkem, se zvládáním toho, co potřebují, se zájmem o dění ve světě kolem, s intimními vztahy, s možností odpočinku ve volném čase a s pocitem bezpečí. Tyto nesouhlasné názory s lepším hodnocením ze stran rodičů mohou být prř́činou nepochopení pocitů starších dospívajících rodiči a v důsledku toho sníženého hodnocení spokojenosti s rodinnými vztahy ze strany starších dospívajících.

Výsledky jsou pouze částečně v souladu se studiemi (Bradley Eilertsen et al., 2012; Sato et al., 2014), které se zabývaly rozdíly v hodnocení kvality života ze strany samotných dětí a dospívajících po léčbě a ze strany jejich rodičů. Tyto studie prokázaly lepší hodnocení kvality života samotnými dětmi a dospívajícími v porovnání s pohledem rodičů bez ohledu na věk.

Jeden z velkých limitů plyne ze samotného použití dotazníku při sběru dat. Nemůžeme s určitostí vědět, do jaké míry byli respondenti upřímní a do jaké míry se nad položkami opravdu zamysleli. Dalším limitem může být nerozlišování mezi diagnostickými skupinami a mezi závažností pozdních následků u dětí a dospívajících po léčbě onkologického onemocnění z důvodu nerovnoměrného zastoupení diagnóz a pozdních následků v rámci věkových skupin.

\section{Závěr}

Celkově výsledky poukazují na rozdílné zdroje kvality života u dětí a dospívajících po léčbě onkologického onemocnění v průběhu jednotlivých věkových období. Zdraví je jediným zdrojem kvality života, který je stabilně velmi důležitý bez ohledu na věk. Spokojenost s ním je však již mezi věkovými skupinami rozdílná. Rodinné vztahy jsou sice také důležitým zdrojem kvality života, ovšem se vzrůstajícím věkem jejich důležitost mírně klesá.

Hodnocení spokojenosti s jednotlivými zdroji kvality života je velice rozdílné u dětí, a to jak v porovnání se staršími dospívajícími, tak v porovnání s pohledem svých rodičů. Děti uvádějí, že jsou mnohem více spokojené s většinou zdrojů kvality života, a to jak v porovnání se staršími dospívajícími, tak v porovnání s pohledem rodičů. U starších dospívajících je situace opačná a rodiče vnímají spokojenost s některými zdroji kvality života lépe, než ji hodnotí sami dospívající. Tyto výsledky by mohly poukazovat na nedostatečnou schopnost zhodnotit a posoudit kvalitu života a následné negativní vlivy onkologického onemocnění u dětí po léčbě. 


\section{LITERATURA}

Badr, H., Chandra, J., Raheem, J. P., Ater, J. L., Urbauer, D., Cruz, C. D., Demark-Wahnefried, W. (2013). Health-related quality of life, lifestyle behaviors, and intervention preferences of survivors of childhood cancer. Journal of Cancer Survivorship, 7, 523-534.

Blatný, M., Kepák, T., Vlčková, I., Jelínek, M., Tóthová, K., Pilát, M., Slezáčková, A., Sobotková, V., Bartošová, K., Hrstková, H., Štěrba, J. (2011). Quality of life of childhood cancer survivors: handicaps and benefits. Československá psychologie, 55(2), 112-125.

Blatný, M., Jelínek, M., Kepák, M. (2016). Subjective quality of life of adolescent and young adult survivors of childhood cancer in long term perspective: Preliminary results of longitudinal study QOLOP. Československá psychologie, 60(1), 82-87.

Bradley Eilertsen, M. E., Jozefiak, T., Rannestad, T., Indredavik, M. S. Quality of Life in Children and Adolescents Surviving Cancer. European Journal of Oncology Nursing, 16, 185-193.

Decker, C. L. (2007). Social support and adolescent cancer survivors: A review of the literature. Psycho-Onco$\log y 16,1-11$.

van Dijk, J., Husiman, J., Moll, A. C., Schouten-van Meeteren, A.YN., Bezemer, P. D., Ringens, P. J., Cohen-Kettenis, P. T., Imho, S. M. (2007). Health-related quality of life of child and adolescent retinoblastoma survivors in the Netherlands. Health an Quality Life Outcomes, 5-65.

Dragomirecká, E. et al. (2006). SQUALA. Přiručka pro uživatele české verze Dotazníku subjektivní kvality života SQUALA. Praha: Psychiatrické centrum Praha.

Eiser, C., Morse, R. (2001). Can parents rate their child's health-related quality of life? Results of a systematic review. Quality of Life Research, 10, 347-357.

Eiser, C., Eiser, J. R., Greco, V. (2004). Surviving childhood cancer: quality of life and parental regulatory focus. Personality and Social Psychology Bulletin, 30, 123-133.

Gordinj, M. S., van Litsenburg, R. R., Gemke, R. J., Huisman, J., Bierings, M. B., Hoogerbrugge, P. M., Kaspers, G. J. L (2013). Sleep, fatigue, and quality of life in survivors of childhood acute lymphoblastic leukemia. Pediatric Blood Cancer, 60, 479-485.

Koutná, V., Blatný, M., Jelínek, M., Kepák, T., Blažková, T. (2014). Sociální opora dětí a adolescentů po léčbě onkologického onemocnění v porovnání s dětmi a adolescenty z běžné populace. Československá psychologie, 58(4), 326-339.

Lehmann, V., Grönqvist, H., Engvall, G., Ander, M., Tuinman, M. A., Hagedoorn, M., Samderman, R., Mattsson, E., von Essen, L. (2014). Negative and positive consequnces of adolescent cancer 10 years after diagnosis: an interview-based longitudinal study in Sweden, Psycho-oncology, 23, 1229-1235.

Long, K. A., Marsland, A. L. (2011). Family adjustment to childhood cancer: A systematic review. Clinical Child and Family Psychology Review, 14(1), 57-88.

Ritchie, M. A. (2001). Sources of emotional support for adolescents with cancer. Journal of Pediatric Oncology Nursing, 18, 105-110.

Rueegg, C. S., Gianinazzi, M. E., Rischewski, J., Popovic, M. B., von der Weid, N. X., Michel, G., Kuehni, C. E. (2013). Health-related quality of life in survivors of childhood cancer: the role of chronic health problems. Journal of Cancer Survivorship, 7(4).

Sato, I., Higuchi, A., Yanagisawa, T., Mukasa, A., Ida, K., Sawamura, Y., Sugiyama, K., Saito, N., Kumabe, T., Terasaki, M., Nishikawa, R., Ishida, Y., Kamibeppu, K. (2014). Cancer-specific health-related quality of life in children with brain tumors. Quality of Life Research, 23, 1059-1068.

Shankar, S., Robison, L., Jenney, M. E. M., Rockwood, T. H., Wu, E., Feusner, J., Friedman, D., Kane, R. L., Bhatia, S. (2005). Health-related quality of life in young survivors of childhood cancer using the Minneapolis-Manchester Quality of Life-Youth Form. Pediatrics, 115(2), 435-442.

Schulte F., Wurz, A., Reynolds, K., Strother, D., Dewey, D. (2016). Quality of life in survivors of pediatric cancer and their siblings: the consensus between parent-proxy and self-reports. Pediatric Blood Cancer, 63(4), 677-683.

Speechley, K. N., Barrera, M., Shaw, A. K., Morrison, H. I., Maunsell, E. (2006). Health- related quality of life among child and adolescent survivors of childhood cancer. Journal of Clinical Oncology, 24(16), 2536-2543. 
Woodgate, R. L., Tailor, K., Yanofsky, R., Vanan, M. I. (2016). Childhood brain cancer and its psychosocial impact on survivors and their parents: a qualitative thematic synthesis. European Journal of Oncology Nursing, 20, 140-149.

Yi, J., Kim, M. A., Sang, J. (2016). Worries of Childhood Cancer Survivors in Young Adulthood. European Journal of Oncology Nursing, 21, 113-119.

Zeltzer, L. K., Lu, Q., Leisenring, W., Tsao, J. C., Recklitis, C., Armstrong, G., Mertens, A. C., Robison, L. L., Ness, K. K. (2008). Psychosocial outcomes and health-related quality of life in adult childhood cancer survivors: a report from the childhood cancer survivor study. Cancer Epidemiology Biomarkers \& Prevention, 17(2), 435-446.

\title{
ELEKTRONICKÉ ZDROJE
}

Národní informačni a vzdělávací portál o onkologických onemocněních dětského věku citace [online]. Brno: Institut biostatistiky a analýz Masarykovy univerzity, 2016 [cit. 13. 12. 2016]. Dostupné z: http://detskaonkologie .registry.cz/index.php?pg=reporting

\section{QUALITY OF LIFE OF CHILDREN AND ADOLESCENTS AFTER TREATMENT OF ONCOLOGICAL ILLNESS - COMPARISON WITH THEIR PARENTS' VIEW}

\author{
T. BLAŽKOVÁ, M. BLATNÝ, T. KEPÁK, M. JELÍNEK, V. KOUTNÁ
}

\section{ABSTRACT}

Most studies of children and adolescents following oncology treatment point to a good quality of life in these individuals. However, their parents' views may differ considerably. They can worry more about the future and the satisfaction of their children. The present study identifies the differences between the satisfaction evaluation of the individual sources of quality of life from the point of view of children and adolescents themselves and from the point of view of their parents. At the same time, it also monitors the differences between different age groups.

The research group consists of 172 children and adolescents after treatment of cancer and their parents. Data on the quality of life of children and adolescents after treatment was obtained using the SQUALA Quality Of Life Questionnaire.

The assessment of satisfaction with specific sources of quality of life is very different for the youngest age group. Children report that they are much more satisfied with most sources of quality of life, both in comparison with older teens and in comparison with parents.

Key words: children and adolescents after treatment of oncological disease, quality of life, parental view

O autorech: Mgr. Tereza Blažková-studuje na FSS MU doktorské studium obor psychologie; Prof. PhDr. Marek Blatný, DrSc. - Psychologický ústav AV ČR, Brno; MUDr. Tomáš Kepák - Klinika dètské onkologie FN Brno; PhDr. Martin Jelínek, Ph.D. - Psychologický ústav AV ČR, Brno; Mgr. Veronika Koutná, Ph.D. - Psychologický ústav AV ČR, Brno. E-mail: blazkova.tereza@outlook.com 
Poslední část dotazníku zjišt'uje, co je pro Tebe v životě důležité a jak jsi s různými věcmi ve svém životě spokojený/á. Opět zde nejsou ani dobré, ani špatné odpovědi, zajímá nás Tvůj názor.

Nejprve si prosím přečti následující seznam hodnot a vyznač, jak moc jsou pro Tebe osobně důležité.

Jak je pro mě důležité...

1. být zdravý

2. nebýt odkázán na pomoc druhých při běžné denní činnosti (např. hygiena)

3. být št’astný, nemít problémy a starosti

4. být v prŕijemném prostředí (např. mít hezké bydlení)

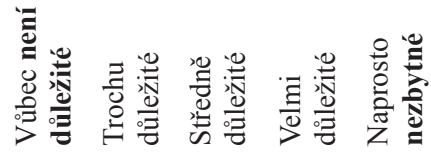

5. dobře spát

6. mít dobré rodinné vztahy (rozumět si a mít se rádi v naší rodině)

7. mít kamarády, dobře si s nimi rozumět

$\mathrm{O} O$

$\bigcirc$

$\mathrm{O}$

O

$\bigcirc$

$\bigcirc$

$\bigcirc \quad \bigcirc$

$\begin{array}{lllll}0 & 0 & 0 & 0\end{array}$

$\mathrm{O} O$

$\mathrm{O}$

$\mathrm{O}$

$\mathrm{O}$

$\mathrm{O} O$

$\bigcirc 0$

$\bigcirc$

○

$\mathrm{O}$

8. mít dobré vztahy s ostatními lidmi (např. učiteli, vrstevníky...)

00000

9. zvládnout vše, co potřebuji

10. chodit s někým (mít kluka/holku)

11. zajímat se o to, co se děje ve světě kolem mě

12. mít víru (věřit v nějakou duchovní moc, sílu jako je Bůh, Kosmos...)

13. odpočívat ve volném čase

14. mít koníčky ve volném čase

15. být v bezpečí, mít jistotu, že se mi nic špatného nestane

$\bigcirc \quad \mathrm{O}$

$\begin{array}{lll}0 & 0\end{array}$

16. spravedlnost (aby k sobě lidé byli „fér“)

00

O

$\mathrm{O}$

$\mathrm{O}$

$\mathrm{O}$

00

$\bigcirc$

$\bigcirc$

$\mathrm{O} O$

17. pravda (aby lidé mluvili pravdu)

$\mathrm{O} O$

$\mathrm{O}$

$\bigcirc 0$

$\bigcirc$

00

0

0

O

18. peníze

○ $\bigcirc$

$\mathrm{O}$

$\mathrm{O}$

0

$\mathrm{O}$

$\mathrm{O}$

19. dobré jídlo

20. být vzdělaný

21. chodit do školy

○ 0

$\bigcirc$

○ $\mathrm{O}$

22. mít možnost hrát si (trávit volný čas) tak, jak chci

00

$\mathrm{O}$

00

23. mít dostatek věcí na hraní, pro svou zábavu

$\bigcirc 0$

$\mathrm{O} O$

$\bigcirc \bigcirc$

$\mathrm{O}$

00

24. dobře vypadat

25. hezky se oblékat

26. mít věci, které se mi líbí, po kterých toužím

$\mathrm{O} O$

0

$\bigcirc \quad \mathrm{O}$

27. jednou mít a vychovávat děti

00

$\mathrm{O}$

00

28. mít jednou zaměstnání, které mě bude bavit

$\mathrm{O} 0$

$\mathrm{O}$

$\mathrm{O}$

0

O

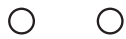

00

0

- 0

0

○ 0

$\bigcirc \quad \bigcirc$

$\bigcirc$ 
Nyní prosím odpověz, jak moc jsi s různými věcmi ve svém životě spokojený/á.

Jak jsi spokojený/á...

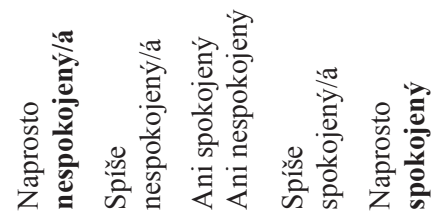

29. s tím, jak jsi zdravý/á

30. s tím, jak jsi samostatný/á, tzn. nezávislý/á na pomoci druhých při běžné denní činnosti (např. hygiena)

31. s tím, jak jsi št’astný/á, bez problémů a starostí

32. s tím, v jakém prostředí žiješ (zda máš např. hezké bydlení)

00

$\mathrm{O}$

$\mathrm{O}$

$\bigcirc \bigcirc$

$\bigcirc$

○

$\begin{array}{lllll}0 & 0 & 0 & 0 & 0\end{array}$

33. s tím, jak dobře spís

34. s tím, jaké jsou vztahy u vás v rodině

35. se svými kamarády (s tím, jaké a kolik jich máš)

○ 0000

00000

00000

36. s tím, jaké máš vztahy s ostatními lidmi (např. učiteli, vrstevníky...)

37. s tím, jak zvládáš to, co potřebuješ

38. se svými důvěrnými vztahy (s tím, zda máš či nemáš kluka/holku)

39. s tím, zda se můžeš dostatečně zajímat o to, co se děje ve světě kolem tebe (např. chtěl/a by ses zajímat víc)

40. se svou vírou

41. s tím, zda můžeš dostatečně odpočívat ve volném čase

42. s uspokojováním svých koníčků

43. s tím, jak se cítiš být $v$ bezpečí (máš jistotu, že se ti nic špatného nestane)

44. s tím, jak jsou lidé spravedliví (jsou k sobě „fér")

45. s tím, jak jsou lidé pravdomluvní

46. s penězi

$\bigcirc \bigcirc$

$\mathrm{O}$

$\mathrm{O}$

$\bigcirc \bigcirc$

$\bigcirc$

$\mathrm{O}$

O 0000

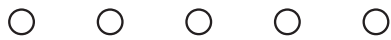

$\bigcirc \bigcirc 0 \quad \bigcirc \quad 0$

O 0000

0
0 00

$\begin{array}{lllll}0 & 0 & 0 & 0 & 0\end{array}$

$\circ \bigcirc 000$

47. s jídlem

48. se svým vzděláním

49. s tím, že můžeš chodit do školy

$\begin{array}{lllll}0 & 0 & 0 & 0\end{array}$

O 0000

O 0000

O 0000

O 0000

50. s tím, zda můžeš trávit volný čas (hrát si) tak, jak chceš

00

000

51. s tím, kolik máš věcí na hraní, pro svou zábavu

00

O

○ 0

○ 0

O

○ 0

O

$0 \quad 0$

52. s tím, jak vypadáš

○ 0

0

O

O

53. s tím, jak chodíš oblékaný/á

54. s tím, zda máš věci, které se ti líbí, po kterých toužíš

○ 0 
Nyní bychom rádi věděli něco o spokojenosti Vašeho dítěte.

Jak si myslíte, že je Vaše dítě spokojené...

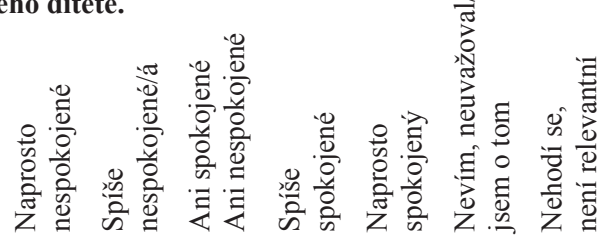

75. s tím, jak je zdravé

76. s tím, jak je soběstačné, tzn. nezávislé na pomoci druhých při běžné denní činnosti (např. hygiena)

77. s tím, jak je št’astné, bez problémů a starostí

78. s tím, v jakém prostředí žije

79. jak dobře spí

80. s tím, jaké jsou vztahy u vás $\mathrm{v}$ rodině

00

○ 0

00

000

81. se svými kamarády (s tím, jaké a kolik jich má)

00

00

0

0

0

00

82. s tím, jaké má vztahy s ostatními lidmi (např. učiteli, vrstevníky...)

83. s tím, jak zvládá vše to, co potřebuje

00

O

○

O

00

00

○ 0

○

O 0

0

0

O

O

00

84. se svými důvěrnými vztahy (s tím, zda má či nemá kluka/holku, zda s někým chodí)

O

○

0

O

0

00

O

O

O

O

00

$\bigcirc 0$

0

0

0

00

85. s tím, zda se může dostatečně zajímat o to, co se děje ve světě kolem něho

86. se svou vírou

87. s tím, zda může dostatečně odpočívat ve volném čase

88. s uspokojováním svých koníčků

89. s tím, jak se cítí být v bezpečí

$\bigcirc$

O

$\bigcirc$

O

O

O

O

00

O

○ 0

O

O

O

00

90. s tím, jak je svět spravedlivý (zda jsou lidé k sobě ,fér"

91. s tím, jak jsou lidé pravdomluvní

92. s penězi

93. s jídlem

94. se svým vzděláním

95. s tím, že může chodit do školy

O 0

00

O

$\bigcirc$

$\mathrm{O}$

$\mathrm{O}$

$\bigcirc$

$\bigcirc \mathrm{O}$

0

O

$\mathrm{O}$

$\mathrm{O}$

$\bigcirc$

96. s tím, zda může trávit volný čas tak, jak chce (po svém)

97. s tím, kolik má věcí ke hraní, pro svou zábavu

$\mathrm{O}$

$\bigcirc$

$\bigcirc$

$\mathrm{O} O$

O

$\bigcirc 0$

$\bigcirc$

$\bigcirc$

O

○

O

$\mathrm{O}$

00

$\bigcirc$

$\bigcirc$

$\bigcirc$

○ 0

0

$\mathrm{O}$

0

O

0

O 0

O 0

000

$\mathrm{O}$

0

$\mathrm{O}$

O

$\mathrm{O}$

98. s tím, jak vypadá

$\mathrm{O}$

O

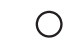

000

99. s tím, jak chodí oblékané

00

00

O

$\mathrm{O}$

$\mathrm{O}$

100. s tím, zda má věci, které se mu líbí, po kterých touží

$\bigcirc 0$

O

0

O 0

○ 0

O 